\title{
Al-Chizan
}

Jurnal Pemikiran Hukum Islam

ISSN 1907-0985, E ISSN 2442-8256

Vol. 15, No. 1, 2019, h. 1-32

DOI: https://doi.org/10.30603/am.v15i1.835

\section{Analisis Yuridis terhadap Perkawinan Perempuan Muallaf dengan Wali Nikah Tokoh Agama}

\author{
Makbul Bakari, Rizal Darwis
}

Pengadilan Agama Kwandang, IAIN Sultan Amai Gorontalo

Email: boele78@gmail.com; rizaldarwis@iaingorontalo.ac.id

Abstract: This research discusses to study and analyze the legal considerations of the Panel of Judges' judgments in Stipulation Number 20/Pdt.P/2012/PA.Smi and Stipulation Number 6/Pdt.P/2013/PA.Sgr. about itsbāt nikah in marriage of muallaf women with marriage guardians of religious leaders, then comparing the results of the two determinations. This research is a type of library research that acts descriptive-analyticalcomparative. The choices used are juridical-normative and syara. The results of this study indicate that the contextual interpretation of the legal text more fulfills a sense of justice in favor of textual interpretation. Stipulation Number 6/Pdt.P/2013/PA.Sgr. which departs from contextual interpretation by considering socio-cultural and legal awareness of the community and contra legem by way of questioning the meaning (supported legal interpretation) of terminology). Honower Stipulation Number 20/Pdt.P/ 2012/PA.Smi which starts from textual-legalistic interpretation cannot fulfill the sense of justice of the community, but can only fulfill procedural demands.

Keywords: Determination of the Court; Muslim Convert, Guardian of Marriage

\section{Juridical Analysis of the Muallaf Women's Marriage with Marriage Guardians of Religious Leaders}

Abstrak: Penelitian ini bertujuan untuk mengetahui dan menganalisis secara yuridis pertimbangan hukum Majelis Hakim pada Penetapan Nomor 20/Pdt.P/2012/PA. Smi dan Penetapan Nomor 6/Pdt.P/2013/PA.Sgr. tentang itsbāt nikah perkawinan perempuan muallaf dengan wali nikah tokoh agama, kemudian mengkomparasikan hasil dari kedua penetapan tersebut. Penelitian ini berjenis penelitian kepustakaaan yang bersifat deskriptifanalitis-komparatif. Pendekatan yang digunakan adalah yuridis-normatif dan 


\section{Analisis Yuridis terhadap Perkawinan Perempuan Muallaf dengan Wali Nikah Tokoh Agama}

syara'. Hasil penelitian ini menunjukkan bahwa penafsiran kontekstual terhadap teks hukum lebih memenuhi rasa keadilan ketimbang penafsiran tekstual. Penetapan Nomor 6/Pdt.P/2013/PA.Sgr. yang bertolak dari penafsiran kontekstual dengan mempertimbangkan sosio-kultural dan kesadaran hukum masyarakat dan melakukan contra legem dengan cara melakukan perluasan makna (penafsiran hukum ekstensif) terhadap terminologi wali hakim hingga mencakup ke dalam pengertian wali muhakkam, cenderung lebih responsif terhadap rasa keadilan masyarakat (keadilan substantif). Sebaliknya Penetapan Nomor 20/Pdt.P/2012/PA.Smi yang bertolak dari penafsiran tekstual-legalistik cenderung tidak dapat memenuhi rasa keadilan masyarakat, tetapi hanya sekedar memenuhi keadilan prosedural.

Kata Kunci: Penetapan Pengadilan; Perempuan Muallaf, Wali Nikah

\section{A. Pendahuluan}

Islam telah meletakan norma dasar bahwa perkawinan yang sah adalah perkawinan yang terpenuhi rukun dan syaratnya. Salah satu rukun yang ada dalam perkawinan adalah kehadiran wali nikah. Dalam Pasal 19 Kompilasi Hukum Islam (KHI) disebutkan "Wali nikah dalam perkawinan merupakan rukun yang harus dipenuhi bagi calon mempelai perempuan yang bertindak untuk menikahkannya." Mengenai wali nikah, terdapat perbedaan pendapat di kalangan fuqaha'. Menurut mayoritas fuqaha', termasuk Imam Syafi'i dan Ahmad bin Hanbal, berpendapat bahwa seorang perempuan tidak diperbolehkan menikahkan dirinya sendiri ataupun perempuan selain dirinya. Menurut Imam Syafi'i, suatu perkawinan tidak sah tanpa adanya wali nikah bagi pengantin perempuan. Sedangkan, bagi calon pengantin laki-laki tidak diperlukan wali nikah untuk sahnya nikah tersebut. ${ }^{2}$ Adanya seorang wali merupakan penentu sah tidaknya suatu perkawinan tersebut. Sebab, wali dari pihak perempuanlah yang akan menyerahkan anaknya kepada pihak laki-laki atau calon mempelai laki-laki dalam hal ijab qabul (serah terima). Orang-orang yang akan menjadi wali harus memenuhi syarat yang telah

${ }^{1}$ Mahkamah Agung RI, Himpunan Peraturan Peraturan Perundang-undangan di Lingkungan Peradilan Agama, (Jakarta: Direktorat Jenderal Badan Peradilan Agama, 2016), 1025 .

${ }^{2}$ Moh. Idris Ramulyo, Hukum Perkawinan Islam: Suatu Analisis dari UU No 1 Tahun 1974 dan KHI (Jakarta: PT Bumi Aksara, 2004), 215. 
ditetapkan oleh syariat. Syarat wali nikah ialah Islam, telah dewasa dan berakal sehat, laki-laki, merdeka, adil, serta tidak sedang dalam ihram haji atau umrah. ${ }^{3}$

Ada dua syarat wali nikah yang telah disepakati oleh para fuqahä. Pertama, cakap hukum (kamāl al-ahliyah) yaitu orang yang sudah dewasa, berakal sehat dan merdeka (bukan berstatus budak); Kedua adalah antara wali nikah dan anak perempuan yang hendak dinikahkannya (al-maulā 'alaih) beragama yang sama. ${ }^{4}$ Berdasarkan pendapat tersebut, seorang anak perempuan yang berbeda keyakinan dengan Bapaknya, maka Bapaknya tidak sah menjadi wali nikahnya. Dengan kata lain, seorang perempuan yang muallaf misalnya tidak sah dinikahkan oleh bapak kandungnya yang masih beragama selain Islam, makanya perempuan muallaf dapat dikategorikan sebagai orang yang tidak memiliki wali.

Hukum Islam dan peraturan perundang-undangan yang berlaku di Indonesia, ${ }^{6}$ seorang perempuan muallaf, yang bapak, paman serta saudarasaudara lelakinya berstaus non muslim, dianggap sebagai perempuan yang tidak memiliki wali nikah, sehingga kewenangan wali nikah beralih kepada

\footnotetext{
${ }^{3}$ Amir Syarifuddin, Hukun Perkawinan Islam di Indonesia (Jakarta: Kencana, 2006), 76.

${ }^{4}$ Wahbah bin Muștafā az- Zuhailī, Al-Fiqh al-Islāmi wa 'Adillatuh, Juz IX dalam Maktabah Syāmilah (Cet. IV; Damaskus: Dār al-Fikr, t.th.), 6700.

${ }^{5}$ Ibnu Qasim ketika berbicara tentang orang yang berhak menerima zakat, mendefenisikan muallaf dengan مؤلفة المسلمين، وهو من أسلم ونيته ضعيفة في الإسلام فتألف بدفع الزكاة له (orang yang baru memeluk agama Islam dan masih lemah pendiriannya terhadap Islam, maka diberikan zakat kepadanya agar hatinya lunak terhadap agama Islam). Lihat, Ibnu Qāsim, Fath al-Qan̄b al-Muj̄̄b Fi Syarh Alfādz al-Qar̄̄b, Juz I (Cet. I; Beirut: Dār Ibn Hazm, 2005 $\mathrm{M} / 1425 \mathrm{H}), 133$.

${ }^{6}$ Pasal 1 ayat (2): Wali Hakim adalah pejabat yang ditunjuk oleh Menteri Agama atau pejabat yang ditunjuk olehnya untuk bertindak sebagai wali nikah bagi calon mempelai wanita yang tidak mempunyai wali; Pasal 2 ayat (1): Bagi calon mempelai wanita yang akan menikah di wilayah Indonesia atau di luar negeri/wilayah extra teritorial Indonesia, tidak mempunyai wali nasab yang berhak atau wali nasabnya tidak memenuhi syarat atau mafqūd atau berhalangan atau adal maka pernikahannya dilangsungkan oleh wali hakim. Lihat Republik Indonesia, Peraturan Menteri Agama Nomor 2 Tahun 1987 yang diubah dengan Republik Indonesia, Peraturan Menteri Agama RI Nomor 30 Tahun 2005 tentang Wali $H$ akim, pasal 1 ayat (2) dan pasal 2 ayat (2).
} 


\section{Analisis Yuridis terhadap Perkawinan Perempuan Muallaf dengan Wali Nikah Tokoh Agama}

unsur pemerintah dalam hal ini yang diberi kewenangan oleh negara adalah penghulu atau biasa dikenal dengan wali hakim. ${ }^{7}$ Sabda Rasulullah saw:

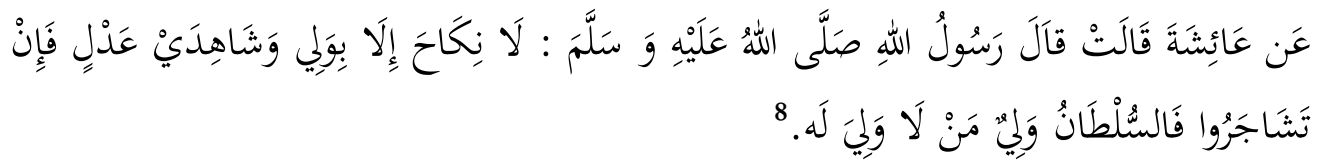

Artinya:

Dari 'Aisyah berkata bahwanya Rasulullah saw. telah bersabda: tidak sah nikah melainkan dengan wali dan dua orang saksi yang adil. Jika wali-wali itu enggan (berkeberatan), maka hakimlah yang menjadi wali orang yang tidak mempunyai wali.

Berdasarkan hadis di atas seharusnya yang menjadi wali nikah dari seorang perempuan muallaf adalah Sultan atau Pemerintah (wali hakim), akan tetapi faktanya, tidak semua perempuan muallaf, melangsungkan perkawinannya melalui Wali Hakim (Penghulu KUA). Artikel ini kiranya dapat merepresentasikan fenomena sosial yang terjadi di masyarakat terhadap praktek perkawinan dengan menggunakan wali nikah tokoh agama dengan membandingkan penetapan Pengadilan Agama Sukabumi Nomor 20/Pdt.P/2012/PA. Smi, tertanggal 11 Juli 2012, dimana Pemohon II adalah seorang perempuan muallaf-yang semula beragama Kristen sehingga semua keluarga laki-lakinya, baik ayah maupun saudara-saudaranya masih beragama Kristen- yang perkawinannya dengan Pemohon I dilangsungkan dengan wali nikahnya adalah tokoh masyarakat/agama setempat, tidak melalui atau menggunakan wali hakim (Kepala KUA setempat), yang kedua Penetapan Pengadilan Agama Singaraja Nomor 6/Pdt.P/2013/PA. Sgr, tertanggal 23 Mei $2013 \mathrm{M}$, yang kasusnya sama yaitu perkawinan perempuan muallaf dengan wali nikah tokoh agama.

${ }^{7}$ Wali Hakim adalah Kepala Negara yang beragama Islam yang mempunyai kekuasaan yang boleh menyangkut orang lain menjadi wali hakim untuk menikahkan seseorang yang berwali hakim. Lihat Hasballah Thaib, Hukum Keluarga dalam Syariat Islam (Medan: Universitas Dharmawangsa, 1983), 53.

${ }^{8}$ Abū al-Hasan bin 'Umar bin Ahmad bin Mahdi bin Masūd bin Nu'mān bin Dīnār ad-Dāruquthniy, Sunan Dār al-Quṭni, Juz. III, dalam al-Maktabah as-Syāmilah (Cet. I; Beirut, Libanon: Muassasah al-Risālah, 2004 M/1424H), 225. 


\section{B. Syarat Wali Nikah}

Al-walāyah (perwalian) adalah suatu bentuk perlindungan dengan penghargaan penuh atas dasar rasa tanggung jawab dan cinta kasih, untuk memberikan pertolongan atas ketidakkuasaan atau ketidakmampuan seseorang dalam melakukan perbuatan-perbuat an hukum atas hartanya atau hal yang berkaitan dengan dirinya, atau dengan kata lain, wali adalah orang yang diberi kekuasaan atas sesuatu. Seseorang dapat bertindak menjadi wali apabila memenuhi syarat-syarat yang telah ditentukan dalam hukum Islam, dan para ulama ada yang sepakat dan ada yang berbeda pendapat dalam masalah syarat-syarat yang harus dipenuhi seorang wali.

1. Syarat Wali Nikah yang Disepakati di Kalangan Fuqahā (Ahli Fikih)

Fuqahā (ahli fikih) menyepakati ada 2 (dua) syarat wali: Pertama, cakap hukum (kamālu al-ahliyyah), artinya orang yang hendak menjadi wali nikah haruslah orang cakap dalam melaksanakan sebuah perbuatan hukum. Kriteria orang yang cakap hukum di antaranya adalah sudah dewasa (albuhug), berakal sehat (al-aql) (tidak gila), dan orang yang merdeka (alhuriyyah) bukan budak atau hamba sahaya; Kedua, ada kesamaan agama dan keyakinan antara wali dan anak perempuan yang menjadi perwliannya (Ittifă $q$ dìn al-wať wā al-maulā 'alaih).' Berdasarkan syarat kedua ini, ulama Hanābilah dan ulama Hanafiyah sepakat mengatakan bahwa seorang ayah yang non muslim tidak boleh menjadi wali dalam perkawinan anak perempuannya yang muslimah, artinya apabila hal itu dilaksanakan maka perkawinannya dianggap tidak sah. Senada dengan pendapat kedua mazhab tersebut, di kalangan ulama Syāfi'iyyah dan Mālikiyah juga tidak membolehkan wali nikah non muslim terhadap anak perempuan muslimah, hanya saja menurut ulama Syāfi'iyah seorang ayah yang non muslim dapat menjadi wali nikah bagi anak perempuannya yang non muslimah, apakah calon suaminya beragama yang sama dengannya atau beragama Islam tidak menjadi masalah menurut mazhab ini. Sedangkan menurut ulama Mālikiyah seorang ayah yang muslim dapat menjadi wali bagi anak perempuannya yang non muslim asalkan dari golongan ahli kitab (al-kāfirah al-kitābiyah). Adapun seorang ayah yang murtad, tidak boleh menjadi wali nikah secara mutlak. ${ }^{10}$ Menurut Wahbah bin Muṣtafā az-Zuhailī yang menjadi alasan atau

\footnotetext{
${ }^{9}$ Wahbah bin Mușțafā az- Zuhailī, Al-Fiqh al-Islāmi wa 'Adillatuhu, 185.

${ }^{10}$ Wahbah bin Muṣtafāa az- Zuhailī, Al-Fiqh al-Islāmi wa 'Adillatuhu, 185.
} 


\section{Analisis Yuridis terhadap Perkawinan Perempuan Muallaf dengan Wali Nikah Tokoh Agama}

dalil sehingga seorang ayah yang non muslim tidak boleh menjadi wali nikah bagi anak perempuannya yang muslimah sebagai berikut:

a. Dalil Naqti:

Dalil nasqli yang dijadikan dasar adalah Q.S. at-Taubah/9: 71; Q.S. al-Anfāl/8:73, Q.S. an-Nisā/4:141) dan hadis riwayat ad-Dāruquthn̄̄ ${ }^{11}$

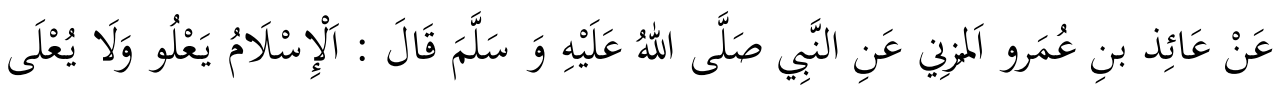

Artinya:

Dari ' $\bar{A}$ 'id bin 'Umar al-Muzn̄̄ dari Nabi saw, berkata ia: Islam itu tinggi dan tidak ada (selainnya) yang dapat menandinginya.

\section{b. Dalil 'Aqli:}

Alasan disyaratkannya antara wali nikah dan anak perempuan yang menjadi perwaliannya harus seagama, adalah agar antara ayah dan anak sama persepsi atau pandangan dalam mencari kemaslahatan (perkawinan), karena biar bagaimanapun juga, faktor agama masih sangat dominan menjadi bahan pertimbangan ketika seseorang mengambil suatu keputusan/kebijakan, sehingga dikhawatirkan apabila ayah sebagai penentu kebijakan dalam hal perkawinan putrinya mengambil keputusan-misalnya mementukan calon suami bagi putrinya- berdasarkan kriteria agama yang dianutnya sementara si anak perempuan yang menanggung akibatnya dengan sebab apa yang diputuskan ayahnya ternyata bertentangan dengan kriteria ajaran agama yang dianutnya. Alasan lainnya adalah menyerahkan urusan perempuan muslimah khususnya urusun perwalian nikah, atau urusan muslim pada umumnya kepada orang non muslim itu sama halnya menghinakan atau merendahkan harkat dan martabat kaum muslimin di hadapan non muslim (kafir). ${ }^{12}$

\footnotetext{
${ }^{11}$ Abū al-Hasan bin 'Umar bin Ahmad bin Mahdi bin Masūd bin Nu'mān bin Dīnār
} ad-Dāruquthniy, Sunan Dār al-Quṭniy, Bāb Mahar, Juz. III, 252. Lihat juga Muhammad bin Ismā’̄il Abū 'Abdillāh al-Bukhārī al-Ja'fī, al-Jāmi'u as-Ṣah̄̄h al-Mukhtaṣar (Ṣah̄̄h alBukhārī), Bāb as-Syahādah 'alā al-Ansāb, Bāb Idzā Aslama as-Ṣābī fa Māta, Juz I (Cet. III; Beirut: Dār Ibn Katsīr, 1987 M/1407 H), 454.

${ }^{12}$ Wahbah bin Muṣtafā az- Zuhailī, Al-Fiqh al-Islāmi wa 'Adillatuhu, 186. 


\section{Syarat Wali Nikah yang Tidak Disepakati di Kalangan Fuqahā}

Ada 3 aspek yang tidak disepakati di kalangan fuqahā terkait syarat wali nikah, yaitu:

1. Laki-laki

Syarat ini merupakan syarat yang ditetapkan oleh jumhur ulama yakni ulama Syāfi'iyah, Mālikiyah dan Hanābilah selain Hanafiyah. Mengenai syarat laki-laki, jumhur ulama dari ketiga mazhab, berpendapat bahwa wanita tidak boleh menjadi wali bagi orang lain dan tidak boleh wanita mengawinkan dirinya sendiri. Sementara golongan Hanafiyah berpendapat bahwa laki-laki bukanlah merupakan syarat nikah. Sehingga menurut golongan ini, seorang perempuan yang telah dewasa dan berakal sehat dapat menikahkan dirinya sendiri dan juga perempuan lain, apakah ia bertindak sebagai wali atau sebagai wakil wali (dari orang lain). ${ }^{13}$ Bagi kelompok yang tidak membolehkan perempuan menjadi wali nikah, beralasan kepada hadīṣ yang diriwayatkan oleh Ibnu Mājah dan Dāruquthnī:

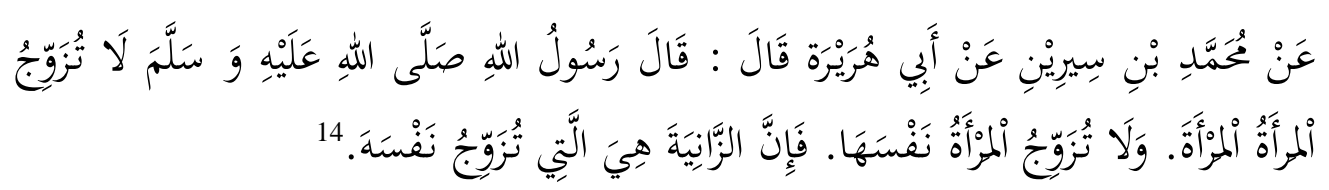

Hadis tersebut melarang wanita mengucapkan șighāt al-ijāb dalam akad nikah bahkan pelakunya dinyatakan sebagai pezina, larangan adalah menujukkan batalnya pekerjaan yang dilarang, ${ }^{15}$ yaitu larangan wanita menikahkan wanita lain dan wanita yang menikahkan dirinya. Jika

${ }^{13}$ Wahbah bin Muștafā az- Zuhailī, Al-Fiqh al-Islāmi wa 'Adillatuhu, 186.

${ }^{14}$ Muhammad bin Yazīd Abū 'Abdillāh al-Gazawainī, Sunan Ibnu Mājah, Bāb Lā Nikāḥa illā biwaliȳ̄, Juz I (Beirut: Dār al-Fikr, t.th.), 606. Lihat juga Abū al-Hasan bin 'Umar bin Aḥmad bin Mahdi bin Masūd bin Nu'mān bin Dīnār ad-Dāruquthniy,Sunan Dār al-Quṭnī, Bāb Kitāb an-Nikāḥ, Juz. III, h. 227.

${ }^{15}$ Dalam kaidah ushül fiqh disebutkan النهي يدل على فساد المنهى عنه menurut jumhur ulama fikih maupun ushūl fiqh bahwa larangan secara mutlak, menurut syariat menunjukan fasadnya sesuatu yang dilarang baik seustu itu berupah ibadah (hubungan vertikal) maupun dalam mu'āmalah (hubungan horizontal). Dalam ibadah contohnya larangan sholat dan puasa bagi perempuan yang sedang dalam keadaan haid, menunjukan batalnya sholat dan puasanya jika dijalankan dalam keadaan haid. Dalam mu'āmalah contohnya adalah larangan jual beli uang, misalnya menjual uang satu dirham dengan harga dua dirham, juga mengisyaratkan batanya jual beli tersebut jika dilakukan dengan cara itu. Lihat Jalāluddin Muhammad bin Aḥmad bin Muhammad bin Ibrāhīm al-Mahalli as-Syāfi'i, Syarh al-Warqāt fí Ușūl al-Fiqh, Juz 1 (Cet. I; Palestina: Jāmi'ah al-Quds', 1999 M/1420 H), 118. 


\section{Analisis Yuridis terhadap Perkawinan Perempuan Muallaf dengan Wali Nikah Tokoh Agama}

perbuatan ini dilarang terhadap wanita, maka wanita yang menikahkan orang lain atau menikahkan dirinya sendiri, perkawinannya tidak sah. Tegasnya akad nikah yang walinya wanita itu hukumnya tidak sah dan begitu pula wanita yang menikahkan dirinya sendiri juga hukumnya tidak sah menurut kelompok ini.

\section{Adil (Istiqāmah ad-Dìn)}

Mengenai syarat adil atau cerdas ulama Syāfi'iyah berpendapat bahwa wali harus seorang yang adil dan cerdas. Alasannya perkataan Ibn 'Abbas ra:

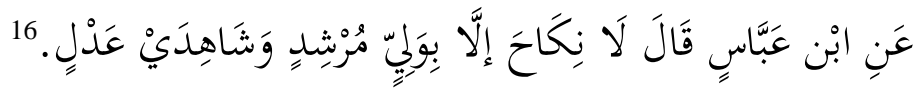

Artinya:

Dari Ibn 'Abbās r.a beliau berkata: Tidak sah nikah kecuali dengan wali yang cerdas dan dua orang saksi yang adil.

Menurut ulama Syāfi'iyah yang dimaksud dengan cerdas dalam perkataan Ibn 'Abbas di atas adalah adil. Maksud adil disini adalah seseorang yang selalu memelihara agama dengan jalan melaksanakan segala yang diwajibkan dan tidak pernah melakukan perbuatan dosa besar serta terhidar dari selalu berbuat dosa kecil. Sedangkan menurut ulama Hanafiyah dan Mālikiyah adil bukanlah merupakan syarat wali nikah, sehingga menurut mereka seorang wali, apakah dia fāsiq ataukah 'adil sah menikahkan putirnya. ${ }^{17}$

3. Cerdas (ar-Rusyd)

Ulama Hanābilah mendefinisikan ar-rusyd dengan "mengetahui urusan kesepadanan (kafa'ah) dan urusan kemaslahatan perkawinan bukan dalam arti pintar mengurus harta kekayaan". Sedangkan ulama Syāfi'iyah mendefinikan ar-rusyd dengan "pintar mengelola harta" (tidak mubazir). ${ }^{18}$ Menurut kedua kelompok ini, ar-rusyd merupakan syarat wali nikah, sedangkan di kalangan Hanafiyah dan Mālikiyah, ar-rusyd bukan merupakan syarat wali nikah. ${ }^{19}$

\footnotetext{
${ }^{16}$ Muhammad bin Idrīs as-Syāfi'ī Abu 'Abdillāh, al-Um, Bāb an-Nikāh bi Walīy, Juz VII (Beirut: Dār al-Ma'rifah, 1393 H), 222.

${ }^{17}$ Wahbah bin Muștafā az- Zuhailī, Al-Fiqh al-Islāmi wa 'Adillatuhu, 186-187.

${ }^{18}$ Wahbah bin Muștafā az- Zuhailī, Al-Fiqh al-Islāmi wa 'Adillatuhu, 187.

${ }^{19}$ Wahbah bin Muștafā az- Zuhailī, Al-Fiqh al-Islāmi wa 'Adillatuhu, 188.
} 


\section{Kedudukan Wali dalam Perkawinan Perspektif Fikih}

Perdebatan tentang wali nikah dalam suatu akad perkawinan sudah lama dibicarakan oleh para ahli hukum Islam, terutama tentang kedudukan wali dalam akad tersebut. Sebagian para ahli hukum Islam mengatakan bahwa perkawinan yang dilaksanakan tanpa wali, perkawinan tersebut tidak sah karena kedudukan wali dalam akad perkawinan merupakan salah satu rukun yang harus dipenuhi. ${ }^{20}$

Wali merupakan syarat sahnya akad nikah dan tidak sah suatu akad pernikahan tanpa wali, al-Jāzirī menegaskan hal ini sebagai berikut:

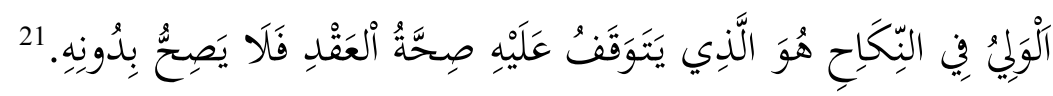

Maknanya: Wali adalah seseorang yang padanya menjadi penentu syahnya akad (pemikahan), maka tidak sah tanpanya.

Wali dalam perkawinan adalah merupakan hal yang penting dan merupakan syarat sah suatu perkawinan, menurut pendapat Imam Malik dan Syafi' $i,{ }^{22}$ keduanya berpendapat tidak sah perkawinan tanpa adanya wali bagi pihak perempuan, sedang bagi laki-laki tidak diperlukan wali. Menurut Imam Abū Ḥanīfah, Zafar, as-Sya'bī dan az-Zuhrī bahwa perkawinan tanpa wali dianggap sah bahkan seorang wanita dapat mengawinkan dirinya sendiri asalkan mempelai laki-lakinya sekufu (sederajat) dengannya. ${ }^{23}$

Sayyid Sābiq menjelaskan bahwa wali merupakan suatu ketentuan hukum (haqqu syar $\imath$ ) yang dapat dipaksakan kepada orang lain sesuai dengan bidang hukumnya. Wali ada yang umum dan ada yang khusus. Yang umum yaitu berkenaan dengan diri manusia (individu), sedangkan yang khusus ialah berkenaan dengan individu dan harta benda. Ini sejalan pemaknaan wali yang artikel ini, wali terhadap manusia, yaitu masalah

${ }^{20}$ Abdul Manan, Aneka Masalah Hukum Perdata Islam di Indonesia (Jakarta: Kencana, 2008), 58.

${ }^{21}$ Abdurraḥmān al-Jazīrīi, Al-Fiqhu 'Alā Mazāḥib al-Arb'ah, Juz IV (Beirut: Dār alFikr, t.th.), 4 .

${ }^{22}$ Abū al-Walīd Muhammad bin Aḥmad bin Muhammad bin Ahmad bin Rusyd alQurthūbī, Bidāyah al-Mujtahid wa Nihāyah al-Muqtașad, Juz II (Cet. IV; Mesir: Muṣtafā al-Bābī al-Halabī, 1975 M/1395 H), 8.

${ }^{23}$ Al-Qurthūbī, Bidāyah al-Mujtahid, 8. 


\section{Analisis Yuridis terhadap Perkawinan Perempuan Muallaf dengan Wali Nikah Tokoh Agama}

perwalian dalam perkawinan. ${ }^{24}$ Keberadaan seorang wali dalam akad nikah (perkawinan) adalah suatu yang mesti dan tidak sah akad perkawinan yang tidak dilakukan oleh wali. Wali itu ditempatkan sebagai rukun dalam perkawinan menurut kesepakatan ulama secara prinsip. ${ }^{25}$ adalah:

Permasalahan wali nikah menjadi polemik fuqahā. Penyebabnya

1. Tidak ada ketegasan di dalam al-Qur'an sah atau tidaknya perkawinan tanpa wali;

2. Tidak ada satupun hadis mutawātir yang mengandung dilâlah qậ'îyah sah tidaknya perkawinan tanpa wali, demikian juga tidak ada hadis ahād yang disepakati keshahihannya. ${ }^{26}$ yang mengandung dilâlah qạt'îyah tentang sah atau tidaknya akad nikah tanpa wali.

3. Di samping itu juga naș-naș baik al-Qur'an maupun hadis yang mereka pergunakan, baik yang mengharuskan masih mengandung beberapa kemungkinan (muhtamil), ${ }^{27}$ mungkin memakai wali, mungkin tidak memakai wali.

4. Mazhab Hanafi mengutamakan qiyas dari hadì ahad, sedangkan Mazhab Syafi'i mengutamakan hadì ahad dari pada qiyas. Menurut Mazhab Hanafi, wanita dalam bidang mu’āmalah sama haknya dengan laki-laki, yang oleh karenanya, mereka mengqiyaskan akad nikah kepada akad jual beli (transaksi). Sedangkan Imam Syafi'i berpegang pada hadìs ahad yang berhubungan dengan sebab nuzül Q.S. al-Baqarah/: 232.

5. Mazhab Hanafi berpendirian bahwa suatu perkara yang ditiadakan oleh Syara' dengan perantara lā näfiyah, harus dipandang bahwa yang ditiadakan itu adalah "sempurnayanya", 28 sedangkan Mazhab Syafi'i bahwa suatu perkara yang ditiadakan oleh syara’ dengan lā näfiyah harus dipandang bahwa yang ditiadakan itu adalah "sahnya", 29

${ }^{24}$ Sayid Sābiq, Fiqh as-Sunnah Juz II (Cet. III; Beirut: Dār al-Kitāb al-‘Arabī, 1977 $\mathrm{M} / 1397 \mathrm{H}), 125$.

${ }^{25}$ Amir Syarifuddin Hukum Perkawinan Islam di Indonesia, 69.

${ }^{26}$ Ibrahim Husen, Fiqh Perbandingan dalam Masalah Nikah Talak dan Rujuk, (Jakarta: Yayasan Ihya Ulumuddin, Yayasan Ihya Ulumuddin, 1971), 112.

${ }^{27}$ Al-Qurțūbī, Bidāyah al-Mujtahid wa Nihāyah al-Muqtasad, 9.

${ }^{28}$ Jadi, hadis yang mengatakan, "tidak ada nikah melainkan dengan wali" Mazhab Hanafi menafsirkan dengan “tidak sempurna nikah,"sedangkan Mazhab Syafi'i menafsirkan dengan "tidak sahnya nikah."

${ }^{29}$ Abdul Wahab dan Abd. Muhaimin, Reaktualisasi Hukum Islam dalam Konteks Hukum Nasional (Cet. I; Jakarta: Gaung Persada Press, 2017), 85. 
Akibatnya terjadilah perbedaan dalam menentukan apakah wali nikah termasuk syarat dan rukun nikah atau tidak. Kelompok Mālikiyah, Syāfi'iyah dan Ḥanābilah menjadikan wali sebagai salah satu rukun nikah dan bukan syarat. ${ }^{30}$ Sedangkan mazhab Zahiriyah membedakan antara perempuan yang perawan dan janda, jika mempelai perempuan masih perawan maka wali menjadi rukun perkawinan, sedangkan jika mempelai perempuan sudah janda maka wali bukan menjadi rukun perkawinan, ia boleh kawin tanpa wali. ${ }^{31}$ Berbeda dengan kedua kelompok di atas, kelompok (mazhab) Hanafiyah berpendapat bahwa wali menjadi syarat nikah, dengan catatan hanyalah bagi pernikahan orang yang belum dewasa (saghīr atau saghīrah) dan orang gila meskipun sudah dewasa. Adapun bagi perempuan dewasa dan berakal sehat, baik perawan maupun janda sama sekali tidak ada yang mempunyai kekuasaan untuk menikahkannya. Dia bebas menikahkan dirinya sendiri dengan lelaki yang disukainya asalkan sederajat (kufu). Jika tidak se-kufu, wali berhak menolak dan menfasakh (menggagalkan) akad nikah. ${ }^{32}$ Namun demikian, walaupun mazhab Hanafiyah berpendapat wali perkawinan bukan sebagai rukun perkawinan, mazhab ini berpendapat bahwa jika akan perkawinan dilakukan oleh wali perkawinan, maka wali perkawinan tersebut harus mengindahkan tingkat kedekatan hubungan darah wali dengan mempelai perempuan sebagaimana juga dianut mazhab fikih lainnya. ${ }^{33}$ Jelasnya menurut jumhur ulama, nikah itu tidak sah tanpa wali. Mereka perpendapat bahwa apabila seorang wanita menikahkan dirinya sendiri, maka hukumnya tidak sah. Mereka berpendapat dengan petunjuk nas yang, walaupun ibarat-nya (mantūq) tidak menunjuk secara langsung kepada keharusan adanya wali, tetapi dari ayat tersebut secara isyarat (mafhüm) nash dapat dipahami menghendaki adanya wali. Di antaranya terdapat dalam Q.S alBaqarah (2:221), Q.S al-Baqarah al-Baqarah (2:232), dan Q.S an-Nur (24:32).

${ }^{30}$ Rukun nikah bagi Hanafiyah hanya dua, yakni ijab dan qabul. Sementara itu, menurut Malikiyah ada lima, yaitu wali, mahar, zawj (calon suami), zawjah (calon isteri) dan sighat. Demikian juga bagi Syafi'iyah ada lima dengan perbedaan bentuknya, yaitu zawj, zawjah, wali, dua saksi dan sighat. Lihat Abdurraḥmān al-Jazīrī, Al-Fiqhu 'Alā Mazāhib al-Arb'ah, Juz IV, 16-28.

${ }^{31}$ Ibn 'Ābidin, Radd al-Mukhtār 'alā Durr al-Mukhtār, vol. 4, (Beirut: Dār al-Ihyā' al-Turāth al-'Arabī, t.th), 115.

${ }^{32}$ Sayyid Sābiq, Fiqh as-Sunnah, 128. Lihat pula Abā Zahrah, Muhādarat fì 'Aqd al-Zīwaj wa Asāruh (Beirut: Dār al-Kutub al-Ilmiyyah, t.th), 159.

${ }^{33}$ Ibn 'Ābidin, Radd al-Mukhtār 'alā Durr al-Mukhtār, vol. 4, h. 138. 


\section{Analisis Yuridis terhadap Perkawinan Perempuan Muallaf dengan Wali Nikah Tokoh Agama}

Selain ketiga ayat tersebut terdapat beberapa ḥadīṣ Rasulullah saw yang menguatkan posisi wali dalam pernikahan, salah satunya:

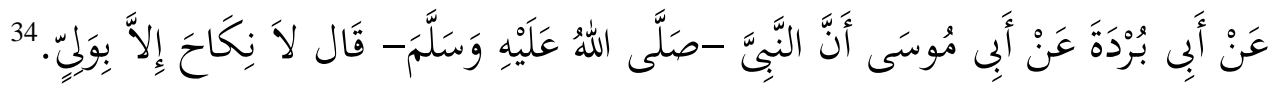

Ulama Mazhab Hanafi menjelaskan bahwa wanita yang tidak bersuami lagi dan gadis mempunyai hak dalam masalah pernikahannya, sehingga wali tersebut meminta izin si gadis untuk menikahkannya.

Menurut Ibnu 'Abidin dan al-Kasāni (pengikut Ḥanafiyah), wali hanya menjadi syarat sah bagi pernikahan orang yang belum dewasa, gila dan budak. Wali tidak diperlukan lagi bagi pernikahan mukallafah (perempuan dewasa yang berakal sehat) yang merdeka sehingga tanpa izin walinya pun pernikahan tetap sah. ${ }^{35}$ Namun si wali berhak menolak selama si perempuan belum melahirkan anak apabila pernikahan tersebut tidak dengan lelaki yang se-kufu. Wali hanya dibutuhkan bagi sabiyy (orang yang belum dewasa). Dengan kedewasaan, hilanglah kekuasaan wali, bada'i al-

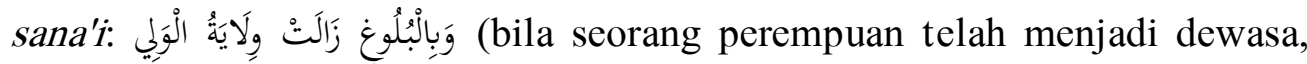
maka hilanglah kekuasaan walinya). ${ }^{36}$

Abu Tsawurī mengemukakan jalan tengah bahwa dalam perkawinan tersebut harus ada kerelaan dari wanita dan walinya sekaligus sehingga masing-masing pihak tidak boleh secara bebas melangsungkan pernikahan tanpa seizin dan keridaan pihak lain. Sementara itu, al-Qurtūbī (salah seorang pengikut Mālikiyah) memberi hak luas kepada wali sehingga perempuan dewasa asalkan masih perawan dapat dinikahkan tanpa harus diminta persetujuannya. Meminta izin kepada perempuan yang akan

${ }^{34}$ Ahmad ibn Hanbal, Musnad al-Imām Ahmad bin Hanbal, Juz IV (Kairo: Muassasah Qurțubah, t.th.), 418.

${ }^{35}$ Di kalangan Hanafiyah, wilāyah al-wāli dibagi menjadi dua; Pertama, wilāyah hatm atau $i j a \bar{b}$ (keharusan), yaitu bagi orang yang belum dewasa dan orang gila meskipun telah dewasa. Kedua, wilayah nadb atau istị̣bāb (bersifat anjuran) yaitu bagi orang dewasa yang berakal sehat. Lihat Abī Bakar bin Mas'ūd al-Kasān̄̄, Badā'i al-Sanā'i fì Tartīb al-Syara'i, Juz II (Beirut: Dār al-Kutub al-Ilmiyyah, t.th.), 241-245; Ibnu 'Abidin, Hāsyiyah Radd al-Mukhtār 'alā al-Durr al-Mukhtār, Juz IV (Beirut: Dār al-Kutub alIlmiyyah, 1994), 154-155.

${ }^{36}$ Abī Bakar bin Mas'ūd al-Kasānī, Badā'i al-Sanā'i, 248-249; Ibn 'Ābidin, Radd al-Mukhtār, 155-156. 
dinikahkan hukumnya hanya sunah, dan tidak wajib, sekalipun dengan lelaki se-kufu. ${ }^{37}$

Ibnu Qudāmah (seorang pengikut Ḥanābilah) berpendapat bahwa sahnya nikah harus dengan wali. Perempuan sama sekali tidak berhak menikahkan dirinya dan juga menikahkaan orang lain, serta tidak boleh mewakilkan kepada selain walinya. Pembatasan terhadap kebebasan perempuan dalam menentukan masa depan rumah tangganya disebabkan oleh lemah akal dan sempit pemikirannya. Untuk menghindarkan perempuan terjerumus ke dalam kerusakan, keberadaan wali mutlak diperlukan. ${ }^{38}$ Demikan pula an-Nawāwi (seorang pengikut Syāfi'iyah) berpendapat bahwa wali menjadi kunci sahnya pernikahan. Apabila ada perempuan yang mengakadkan dirinya sendiri, akad nikahnya tidak sah, kecuali apabila ada izin terlebih dahulu dari walinya. Alasan pelanggaran tersebut di samping perempuan itu sempit akan dan mudah tertipu, juga disebabkan oleh masalah menikahkan merupakan hak wali. ${ }^{39}$

Di sini nampak bahwa hanya golongan Hanafiyah yang memposisikan wali nikah sebagai penyempurna nikah, yang kedudukannya tidak mempengaruhi keabsahan sebuah perkawinan. Sedangkan mayoritas ulama mazhab, berpandangan sebaliknya, bahwa wali nikah menempati posisi yang sangat vital dalam sebuah akad perkawianan. Artinya wali nikah merupakan salah satu rukun yang menentukan sah atau tidaknya suatu perkawianan. Selama perkawinan itu dilaksanakan dengan wali nikah, maka perkawinannya dianggap sah di mata hukum, akan tetapi sebaliknya jika perkawinan itu dilangsungkan dengan tanpa wali nikah, atau dengan wali nikah tetapi tidak memnuhi kriteria sebagaimana ditentukan dalam syaratsyarat wali nikah terdahulu, maka perkawainan tersebut menurut jumhur ulama tidak sah.

\section{Wali Nikah dalam Hukum Positif Islam di Indonesia}

Hukum Islam di Indonesia mengalami perkembangan dari waktu ke waktu. Pada empat dekade awal pasca kemerdekaan, hukum Islam

${ }^{37}$ Abū 'Umar Yūsuf bin 'Abdullāh bin Muhammad al-Qurțūbī, Mawsu'ah Fiqh alMālik (Beirut: Dār al-Kutub al-Ilmiyyah, 1992), 231-234.

${ }^{38}$ Ibnu Qudāmah, Al-Mughnī, Juz VII (Beirut: Dār al-Kutub al- Ilmiyyah, t.th), 337339.

${ }^{39}$ Abī Zakariya Muhyuddīn bin Syaraf al-Nawāwi, Al- Majmō' Syarh alMuhazzab, Juz XVI, (Beirut: Dār al-Fikr, t.th.), 146. 


\section{Analisis Yuridis terhadap Perkawinan Perempuan Muallaf dengan Wali Nikah Tokoh Agama}

mengalami kemajuan pesat. Kemajuan tersebut ditandai dengan adanya usaha untuk mengkonkritkan tiga tiang penyangga bagi berlakunya ukum secara efektif, yaitu (1) aparat penegak hukum mulai dibenahi atau berbenah diri; (2) peraturan-peraturan hukum yang jelas satu demu satu dikeluarkan; dan (3) kesadaran hukum masyarakat mulai dipicu. ${ }^{40}$

Undang-Undang Nomor 1 Tahun 1974 tentang Perkawinan, dan Peraturan Pemerintah Nomor 9 Tahun 1975 tentang Pelaksanaan UndangUndang Nomor 1 Tahun 1974 tentang Perkawinan sebagai hukum formil yang digunakan Hakim di Pengadilan Agama tampak masalah wali nikah belum didefinisikan secara ekplisit sebagai syarat dan rukun nikah. Permasalahan hanya disinggung batas minimal usia nikah, yaitu 19 tahun bagi lelaki dan 16 tahun bagi perempuan, dan harus adanya izin orang tua bagi yang belum bagi perempuan mencapai usia 21 tahun (lihat pasal 6 ayat 2-6 Undang-Undang Nomor 1 Tahun 1974). ${ }^{41}$ Perwalian dalam undangundang ini bukan terkait dengan pernikahan, melainkan lebih pada hubungan orang tua/wali dengan anak ampunannya dalam masalah harta benda (bab X dan XI; pasal $45-54$. $^{42}$

Proses kemajuan hukum Islam pada akhirnya mencapai titik terang setelah dikeluarkannya KHI, yang dasar hukumnya berupa Instruksi Presiden Nomor 1 Tahun 1991 tentang Keput usan Menteru Agama Nomor 154 Tahun 1991. Dengan dua instrumen hukum tersebut, KHI resmi menjadi hukum positif Islam Indonesia, ${ }^{43}$ dan digunakan sebagai hukum materil di seluruh Pengadilan Agama yang ada di negara republik Indonesia. Dalam KHI

${ }^{40}$ Meskipun ketiga pilar tersebut belum dapat berjalan dengan optimal, dengan tingginya kesadaran hukum masyarakat, mereka telah berhasil memancangkan tonggak sejarah. Lihat Wasit Aulawi, "Sejarah Perkembangan Hukum Islam," dalam Amrullah Ahmad et.al, Dimensi Hukum Islam dalam Sistem Hukum Nasional (Jakarta: Gema Insani Press, 1996), 55-56.

${ }^{41}$ Mahkamah Agung RI, Himpunan Peraturan Peraturan Perundang-undangan di Lingkungan Peradilan Agama, 340.

${ }^{42}$ Mahkamah Agung RI, Himpunan Peraturan Peraturan Perundang-undangan di Lingkungan Peradilan Agama, 349-351.

${ }^{43}$ Yang dimaksud dengan hukum positif Islam adalah hukum perdata Islam tertentu yang menjadi hukum positif umat Islam, dan menjadi kompetensi absolut Pengadilan Agama. Kompetensi tersebut berupa penanganan perkara-perkara yang terumus dalam KHI pada tingkat pertama yang terjadi antara umat Islam. Lihat pasal 49 ayat (1) Republik Indonesia, Undang-Undang Nomor 7 Tahun 1989 tentang Peradilan Agama sebagaimana telah diubah keduakalinya Republik Indonesia, Undang-Undang Nomor 3 Tahun 2006 dan Republik Indonesia, Undang-Undang Nomor 50 Tahun 2009. 
tersebut, wali nikah secara tegas dimasukkan sebagai salah satu rukun nikah. Pasal 14 menyebutkan sebagai berikut bahwa "untuk melaksanakan perkawinan harus ada; (a) calon suami; (b) calon Isteri; (c) wali nikah; (d) dua orang saksi; dan (e) ijab dan kabul." ${ }^{\text {4 }}$ Selanjutnya, pasal 19 menyebutkan, "wali nikah dalam perkawinan merupakan rukun yang harus dipenuhi bagi calon mempelai wanita yang bertindak untuk menikahkannya."

\section{E. Wali Nikah terhadap Perkawinan Perempuan Muallaf}

Wali nikah dalam perkawinan merupakan rukun yang harus dipenuhi bagi calon mempelai wanita yang bertindak untuk menikahkannya, oleh karena itu keberadaan wali merupakan rukun yang harus dipenuhi, ada beberapa syarat secara sepintas bahwa syarat wali ialah Islam, laki-laki, dewasa, mempunyai hak perwalian dan tidak terdapat halangan perwalian. Dari sekian banyak syarat untuk sahnya perkawinan menurut hukum Islam, wali nikah sangat penting dan menentukan sah tidaknya sebuah perkawinan. Sebagai nizāmul hayyah (peraturan hidup) yang lengkap dan sempurna, dengan pembentukan masyarakat yang sejahtera, Islam telah menetapkan peraturan-peraturan perkawinan dan kekeluargaan dengan sempurna. ${ }^{46}$

Idealnya sebuah perkawinan dilangsungkan dengan wali nikah, sebagaimana disyaratkan baik dalam fikih Islam maupun peraturan perudang-undangan. Akan tetapi dalam keadaan tertentu, kondisi ideal dimaksud tidak selamanya dapat terpenuhi, dikarenakan berbagai macam sebab yang melatar belakanginya. Adanya persoalan perbedaan agama yang dianut oleh wali nasab dengan anak perempuannya. Dalam kondisi seperti ini, hukum Islam memberikan solusi dengan cara perpindahan hak perwalian dari wali yang tidak memenuhi syarat kepada wali yang memenuhi syarat, dari wali yang dekat (aqrab) kepada wali yang jauh ( $\left.a b^{\prime} a d\right)$.

\footnotetext{
${ }^{44}$ Mahkamah Agung RI, Himpunan Peraturan Peraturan Perundang-undangan di Lingkungan Peradilan Agama, 1024.

${ }^{45}$ Pasal 20-23. Lihat Mahkamah Agung RI, Himpunan Peraturan Peraturan Perundang-undangan di Lingkungan Peradilan Agama, 125-126.

${ }^{46}$ Ahmad Rofiq, Hukum Islam di Indonesia (Jakarta: PT Raja Grafindo Persada,1995), 84.
} 


\section{Analisis Yuridis terhadap Perkawinan Perempuan Muallaf dengan Wali Nikah Tokoh Agama}

Adapun syarat perpindahan wali aqrab kepada wali $a b$ 'ad sebagai berikut: (1) apabila wali aqrab-nya non muslim; ${ }^{47}$ (2) apabila wali aqrab-nya fasik; (3) apabila wali aqrab-nya belum dewasa; (4) apabila wali aqrab-nya gila; dan (5) apabila wali aqrab-nya bisu atau tuli. ${ }^{48}$

Selain perpindahan wali nikah yang mempunyai urutan dekat kepada wali nikah yang jauh, menurut Zainuddin Ali, ada juga perpindahan wali nikah berdasarkan hubungan darah (nasab) kepada wali nikah berdasarkan jabatan, atau yang dikenal dengan wali hakim. Perpindahan dimaksud, uratannya adalah:

1. Wali yang mempunyai urutan dekat dan jauh tidak ada sama sekali;

2. Wali yang mempunyai urutan dekat dan jauh ada, tetapi menjadi calon mempelai pria, sementara wali nikah yang sederajat dengannya (samasama anak paman) sudah tidak ada;

3. Wali yang mempunyai urutan dekat ada, tetapi sementara melakukan ihram (ibadah haji);

4. Wali yang mempunyai urutan dekat ada, tetapi tidak diketahui tempattinggalnya;

5. Wali yang mempunyai urutan dekat ada, tetapi menderita penyakit yang menyebabkan tidak dapat melaksanakan tugas perwaliannya;

6. Wali yang mempunyai urutan dekat ada, tetapi sementara menjalani hukuman penjara yang tidak dapat dijumpai;

7. Wali yang mempunyai urutan dekat ada, tetapi bepergian jauh sejauh perjalanan yang membolehkan shalat qashar;

8. Wali yang mempunyai urutan dekat ada, tetapi menolak untuk mengawinkan (adlal);

9. Calon mempelai wanita menderita sakit gila, sementara wali mujbir-nya (ayah atau kakeknya) sudah tidak ada lagi.

Solusi yang tepat bagi perempuan muallaf menurut fuqahà ' maupun aturan perundangan yang berlaku di Indonesia adalah menikah dengan menggunakan wali nikah dari jalur pemerintah dalam hal ini wali hakim atau penghulu pada setiap Kantor Urusan Agama di Kecamatan.

\footnotetext{
${ }^{47}$ Maksudnya apabila wali aqrab ada tetapi tidak beragama Islam sedangkan calon mempelai wanita beragama Islam.

${ }^{48}$ Timah dan Sohari Sahrani, Fiqih Munakahat Kajian Fiqih Nikah Lengkap, (Jakarta: PT Rajawali Pers, 2010), 97.

${ }^{49}$ Zainuddin Ali, Hukum Perdata Islam di Indonesia, 18.
} 


\section{F. Analisis Yuridis terhadap Pertimbangan Hukum Majelis Hakim dalam Penetapan Nomor 20/Pdt.P/2013/PA.Smi dan Penetapan Nomor 6/Pdt.P/2013/PA.Sgr}

\section{Penetapan Nomor 20/Pdt.P/2013/PA.Smi}

Peran seorang wali dalam sebuah peristiwa perkawinan masih menjadi perdebatan di kalangan ulama mazhab fikih. Mazhab Hanafiyah berpendapat bahwa wali perkawinan bukan merupakan syarat sahnya suatu perkawinan. Perempuan yang mengawinkan dirinya tanpa wali dengan lakilaki yang sekufu perkawinannya dianggap sah. Sedangkan mazhab Malikiyah, Syafi'iyah dan Hanābilah berpendapat bahwa wali perkawinan merupakan rukun dalam perkawinan, oleh karena itu akibat hukum perempuan yang mengawinkan dirinya sendiri atau mengawinkan perempuan lain perkawinannya tidak sah. Pendapat lain tentang wali perkawinan, diriwayatkan oleh Ibn Isḥāq dari Imam Anas ibn Mālik, yakni bahwa wali perkawinan hukumnya sunah dan bukan merupakan syarat sahnya suatu perkawinan, melainkan hanya syarat untuk kesempurnaan perkawinan. $^{50}$

Fenomena di atas tak dapat dielakan, terjadi juga di kalangan hakim Pengadilan Agama, yang memang dalam memutus suatu perkara yang dihadapinya tidak jarang merujuk kepada pendapatpendapat ulama mazhab, ketika kasus yang ditanganinya belum diat ur dalam at uran perundangan.

Pemikiran majelis hakim seputar wali dalam perkawinan khususnya wali nikah tokoh agama, dapat ditelusuri dalam penetapan ini. Setelah membaca dan menganalisanya, ada beberapa hal yang menarik perhatian untuk dianalisis lebih jauh.

Pertama, mengenai diktum amar penetapan, dalam hal ini, majelis hakim menolak permohonan para pemohon, itu artinya majelis hakim berpendapat bahwa perkawinan in casu yang dilaksanakan oleh kedua mempelai dengan menggunakan wali nikah tokoh agama setempat, dan bukan wali hakim dari unsur pemerintah dalam hal ini KUA Kecamatan, dianggap tidak sah.

${ }^{50}$ Abdurraḥmān al-Jazīrī, al-Fiqhu 'Alā Mazāḥib al-Arb'ah, Juz IV (Kairo: alMaktabah al-Tijāriyah al-Kubra, 1969), 4, 11, 12 dan 51; 


\section{Analisis Yuridis terhadap Perkawinan Perempuan Muallaf dengan Wali Nikah Tokoh Agama}

Dalam pertimbangan hukumnya majelis hakim melandaskan pendapatnya dimulai dengan pasal $14 \mathrm{KHI}$, tentang rukun nikah dimana salah satu diantaranya adalah wali nikah sebagai berikut:

Menimbang, bahwa untuk syahnya perkawinan, haruslah dipenuhi seluruh unsur/ rukun perkawinan yang menurut Pasal 14 KHI, rukun perkawinan tersebut adalah Calon Suami, Calon Isteri, Wali nikah, dua orang saksi serta Ijab dan Kabul $;{ }^{51}$

Kemudian disusul dengan pasal 20 KHI yang menetapkan kriteria wali nikah yang mana di antaranya adalah wali nikah haruslah seorang muslim, jika kriteria tersebut tidak terpenuhi, dengan kata lain jika wali nikah dari garis keturunan/nasab tidak ada atau tidak memenuhi syarat maka hak perwalian berpindah kepada unsur pemerintah (wali hakim) dalam hal ini Penghulu/Kepala pada KUA Kecamatan, sebagai berikut:

Menimbang, bahwa syarat sebagai seorang wali dijelaskan pada Pasal 20 KHI, seorang wali selain harus balig juga disyaratkan harus seorang muslim, maka oleh karena orang tua Pemohon II bukanlah seorang muslim, hak perwaliannya beralih kepada wali hakim yakni Kepala Kantor Urusan Agama yang mewilayahi tempat tinggal Pemohon II; ${ }^{52}$

Sedangkan untuk menentukkan kriteria wali hakim haruslah dari unsur KUA Kecamatan, majelis hakim berpegang pada Perat uran Menteri Agama Republik Indonesia Nomor 30 Tahun 2005 tentang Wali Hakim Pasal 1 ayat (2):

Menimbang, bahwa sesuai dengan ketentuan Peraturan Menteri Agama RI Nomor 30 Tahun 2005 tentang Wali Hakim Pasal 1 ayat (2) berbunyi:

Wali Hakim, adalah Kepala Kantor Urusan Agama Kecamatan yang ditunjuk oleh Menteri Agama untuk bertindak sebagai wali nikah bagi calon mempelai wanita yang tidak mempunyai wali.

\footnotetext{
${ }^{51}$ Put usan Nomor 20/Pdt.P/2013/PA.Smi

${ }^{52}$ Putusan Nomor 20/Pdt.P/2013/PA.Smi
} 
Pasal 2 ayat (1) berbunyi:

Bagi calon mempelai wanita yang akan menikah di wilayah Indonesia atau di luar negeri/di luar wilayah teritorial Indonesia, tidak mempunyai wali nasab yang berhak atau wali nasabnya tidak memenuhi syarat, atau mafqud, atau berhalangan, atau adhal, maka pernikahannya dilangsungkan oleh wali hakim. ${ }^{53}$

Sampai di sini kemudian majelis hakim berkesimpulan dengan suara bulat bahwa perkawinan antara Pemohon I dengan Pemohon II tidak sah karena tidak memenuhi salah satu rukun nikah yaitu wali hakim, tanpa melalui acara pembuktian sebagaimana lazimnya persidangan, majelis hakim hanya mencukupkan acara pemeriksaannya sampai pada tahap pembacaan permohonan, kemudian beranjak langsung ke acara musyawarah majelis dengan menghasilkan penetapan dengan suara bulat menolak permohonan para Pemohon.

Kedua, melihat kronologis jalannya pemeriksaan perkara, tampak dengan jelas majelis hakim yang menangani perkara ini, berpendapat bahwa dengan diakuinya posita yang menerangkan tentang status orang tua kandung pemohon II yang masih beragama Kristen oleh kedua mempelai, menyebabkan pemeriksaan perkara dicukupkan sampai di situ, tidak harus berlama-lama sampai ke acara pembuktian.

Penetapan semacam ini, secara yuridis-formal tidak keliru karena meskipun tidak melalui proses pembuktian, ${ }^{54}$ dengan

\footnotetext{
${ }^{53}$ Lihat Putusan Nomor 20/Pdt.P/2013/PA.Smi

${ }^{54}$ Model pemeriksaan seperti ini jarang terjadi, biasanya majelis hakim sebelum mengambil kesimpulan menolak atau mengabulkan sebuah permohonan/gugatan tetap melakukan pembuktian terlebih dahulu, apalagi jenis amar putusannya adalah menolak, yang menurut hukum acara secara terminologis adalah hasil dari penilaian fakta persidangan yang merupakan ranah hukum materiil. Jika fakta tersebut terbukti maka diktum amarnya adalah mengabulkan, tetapi sebaliknya jika tidak terbukti maka diktum amar putusannya adalah menolak. Hal ini berbeda dengan ranah hukum formil yang hanya menilai formalitas surat permohonan/gugatan, cukup dengan membaca dan meneliti surat gugatan pada saat pembacaan surat gugatan, tanpa harus melalui pembuktian, majelis hakim sudah dapat menjatuhkan putusan/penetapan dengan diktum amar menerima permohonan/gugatan jika dalam pemeriksaan tidak dijumpai cacat formal atau sebaliknya menyatakan permohonan/ gugatan tidak dapat diterima, jika surat permohonan/gugatan terdapat cacat formal.
} 


\section{Analisis Yuridis terhadap Perkawinan Perempuan Muallaf dengan Wali Nikah Tokoh Agama}

ditemukannya fakta tentang agama wali perkawinan mempelai perempuan yang berbeda dengan calon pengantin perempuan, maka secara faktual majelis hakim sudah dapat mengkualifisir fakta hukum tersebut dengan menghubungkannya pada pasal-pasal tentang persyaratan wali perkawinan, untuk kemudian dikonstituir dengan diktum amar putusan apakah menolak atau mengabulkan permohonan tersebut. Dalam kasus ini, majelis hakim pada kongklusinya berkesimpulan menolak permohonan para pemohon.

\section{Penetapan Nomor 6/Pdt.P/2013/PA.Sgr}

Berbeda dengan Penetapan sebelumnya, pada Penetapan ini, majelis hakim yang menangani permohonan ini justru mengabulkan permohonan para Pemohon yang dalam diktum amarnya menyatakan sah perkawinan antara Pemohon I dan Pemohon II. It u artinya majelis hakim berpendapat bahwa perkawinan kedua mempelai adalah sah secara hukum Islam, meskipun perkawinannya tidak menggunakan wali nasab ataupun wali hakim.

Adapun yang menjadi pertimbangan hukum sehingga permohonan tersebut oleh majelis hakim dikabulkan, adalah berdasarkan kepada adat istiadat setempat yang mengakomodir tokoh agama sebagai wali nikah, di samping karena tingkat pemahaman keagamaan masyarakat setempat yang masih relatif kurang, terutama dalam hukum Islam, khususnya bidang perkawinan. Hal keadaan ini sebagaimana tergambar dalam pertimbangan majelis hakim berikut:

Menimbang, bahwa berkaitan dengan yang bertindak sebagai wali nikah Pemohon II adalah seorang tokoh agama Islam atau ustadz, bukan sebagaimana ketentuan Pasal 3 Ayat (1), (2) dan (3) Peraturan Menteri Agama Republik Indonesia Nomor 30 Tahun 2005, Majelis Hakim perlu mempertimbangkan beberapa aspek yang menjadi sebab hal tersebut terjadi, antara lain;

1. Sudah menjadi kebiasaan masyarakat sekitar, bahwa semua pengurusan pernikahan dipasrahkan kepada tokoh agama seperti TOKOH MASYARAKAT,

${ }^{55}$ Kalimat "TOKOH MASYARAKAT" adalah hasil anonimisasi dalam putusan/penetapan tersebut, sebagai upaya menjaga privasi dari tokoh tersebut. Anonimisasi merupakan prasyarat yang sudah menjadi aturan baku apabila suatu putusan/penetapan akan dipublikasi dalam webside direkotori Putusan Mahkamah Agung. 
2. Sudah menjadi kebiasaan di masyarakat untuk menunjuk orang yang dianggap memiliki ilmu pengetahuan di bidang agama yang cukup, untuk mentaukilkan ijab kabul, bahkan ditunjuk sebagai wali nikah bagi wanita yang tidak memiliki wali nasab;

3. Adanya tingkat pemahaman dan pengetahuan masyarakat yang minim tentang masalah perwalian dalam pernikahan; ${ }^{56}$

Selanjutnya untuk memperkuat basis argumentasinya, majelis hakim mengemukan dalil atau pendapat hukum Islam yang dikutip dari Kitab Nihāyah al- Muhtāj Lì Syarḥ al-Minhāj Juz 20, hal 308, sebagai berikut:

Menimbang, bahwa tentang masalah ini Majelis Hakim mengemukakan doktrin Hukum Islam dalam kitab Nihaayat AlMuhtaaj Li Syarh al-Minhaaj Juz 20 Hal 308 yang diambil alih menjadi pertimbangan Majelis Hakim yang menjelaskan tentang Wali Muhakkam sebagai berikut :

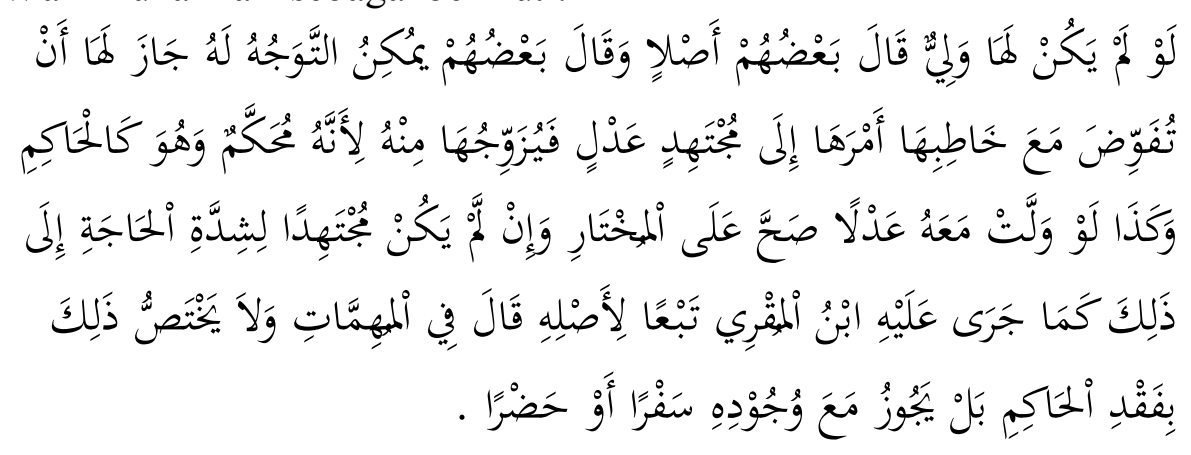

Artinya: "Jika seorang perempuan tidak mempunyai wali (nasab), sebagian Ulama Syafiiyah berpendapat bahwa diperbolehkan bagi seorang perempuan bersama calon suaminya menyerahkan urusannya (perwaliannya) kepada seorang laki-laki mujtahid yang adil, agar mujtahid tersebut menikahkan perempuan itu dengan calon suaminya, karena mujtahid tersebut adalah muhakkam (orang yang dipersamakan dengan hakim) dan muhakkam kedudukannya seperti hakim. Begitu pula bila perempuan tersebut menyerahkan kepada seorang laki-laki yang adil maka menurut pendapat yang mukhtar (terpilih) adalah sah, meskipun ia belum mencapai derajat mujtahid karena terdapat suatu kepentingan yang mendesak. Ibnu al-Muqn̄̄ berpendapat di dalam al-Muhmāt: kebolehan (wali muhakkam) tersebut tidak hanya diperuntukkan untuk kondisi tiadanya wali

${ }^{56}$ Penetapan Nomor 6/Pdt.P/2013/Pa. Sgr 


\section{Analisis Yuridis terhadap Perkawinan Perempuan Muallaf dengan Wali Nikah Tokoh Agama}

\section{hakim bahkan meskipun terdapat wali hakim pun baik dalam perjalanan atau ditempat tetap diperbolehkan" ${ }^{67}$}

Berdasarkan prosedur dan alur persidangan serta argumentasi hukum yang telah dipaparkan di atas, tampak jelas kelihatan secara kasat mata, bahwa majelis hakim dalam perkara ini, berusaha sedapat mungkin untuk bersikap hati-hati dalam mengambil keputusan, hal ini dapat diketahui dengan sikap majelis hakim yang memberi kesempatan kepada para Pemohon untuk mengemukakan pendapatnya sampai dalam tahapan pembuktian,-hal inilah yang membedakannya dengan majelis hakim pada kasus pertama,- sehingga dengan begitu majelis hakim dapat mengeluarkan putusannya tidak hanya berdasarkan mempertimbangkan aturan hukum secara legal-formal, tetapi juga mempertimbangkan adat kebiasaan yang berlaku di daerah setempat. Hal ini sejalan dengan qaidah uṣūl al-fiqh, bahwa menetapkan hukum berdasarkan al-'urf(adat istiadat setempat) sama kedudukannya dengan menetapkan hukum dengan nash (al-qur'an dan hadis), sebagaimana pendapat dalam kitab al-mabsüt yang dinukil oleh Abu Zahrah. ${ }^{58}$ Akan tetapi pertimbangan hukum dengan berdasarkan pada adat setempat, tidak serta merta dapat diterapkan pada setiap kasus selama masih ada aturan dari pasal-pasal tertentu yang dapat diterapkan pada kasus yang sama. Sebagaimana al-'urftidak dapat diterapkan selama masih ada nash alQur'an dan hadis. ${ }^{59}$

Terlihat bahwa majelis hakim pada kasus yang kedua ini, lebih cenderung melakukan pendekatan yang kontekstual tidak hanya melakukan pendekatan secara normatif dengan menerapkan pasal-pasal dalam peraturan perundangan secara legal-formal saja, tetapi mempertimbangkan faktor sosio-kultural masyarakat setempat.

Berdasarkan kondisi sosial masyarakat Bali yang seperti dikemukakan di atas, maka Majelis Hakim dalam perkara a quo melakukan

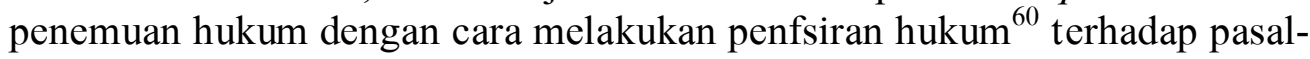

${ }^{57}$ Penetapan Nomor 6/Pdt.P/2013/Pa. Sgr

${ }^{58}$ Teks aslinya sebagai berikut: " "الثبت بالعرف كالثابت بالنص/ Lihat Muhammad Abū Zahrah, Usul al-Fiqh (t.tp.: Dār al-Fikr al-'Arabi), 273.

${ }^{59}$ Muhammad Abū Zahrah, Ușul al-Fiqh, 273.

${ }^{60}$ Penafsiran hukum dengan cara menyesuaikan bunyi teks undang-undang dengan kondisi sosial masyarakat setempat juga dikenal dengan metode penafsiran hukum sosiologis atau teleologis. Metode ini menerapkan makna Undang-undang berdasarkan tujuan kemasyarakatan. Di sini hakim menafsirkan undang-undang sesuai dengan tujuan 
pasal yang dianggap relevan dengan kasus yang dihadapi, salah satunya adalah melakukan contra legem terhadap aturan hukum wali hakim yang terdapat dalam Peraturan Menteri Agama (PMA) Republik Indonesia Nomor 30 Tahun 2005 pasal 1 ayat 2 dengan cara memperluas makna yang dikandung wali hakim, ${ }^{61}$ tidak saja Kepala Kantor Urusan Agama (KUA) Kecamatan, tetapi menjangkau kepada orang yang ditunjuk oleh kedua mempelai yang dikenal dalam terminologi fikih sebagai wali muhakkam. ${ }^{62}$

Penafsiran hukum model ini dalam ilmu hukum dikenal dengan istilah metode penafsiran hukum ekstensif, yaitu metode interpretasi yang membuat penafsiran melampaui batas yang diberikan oleh penafsiran gramatikal $^{63}$. Seperti perkataan menjual dalam Pasal 1576 KUH Perdata, ditafsirkan bukan hanya jual beli semata-mata, tetapi juga "peralihan hak". ${ }^{64}$ Singkatnya penafsiran model ini coraknya adalah meninggalkan makna tekstual dan berpaling menggunakan makna kontekstual, dikarenakan situasi dan kondisi yang melatar-belakanginya.

\section{G. Analisis Komparatif}

Mencermati posisi dan pertimbangan hukum dari kedua penetapan tersebut dapat diketahui bahwa majelis hakim Pengadilan Sukabumi memilih pendekatan legal-formal, yaitu suatu cara dimana majelis hakim

pembentuk undang-undang, titik beratnya adalah pada tujuan undang-undang itu dibuat, bukan pada bunyi kata-katanya saja. Peraturan perundang-undangan yang telah usang, disesuaikan penggunaannya dengan menghubungkan dengan kondisi dan situasi saat ini atau situasi sosial yang baru. Lihat Abdul Manan, Penerapan Hukum Acara Perdata di Lingkungan Peradilan Agama, 281.

${ }^{61}$ Lihat Penetapan Nomor 6/Pdt.P/2013/Pa. Sgr

${ }^{62}$ Kata muhakkam merupakan kata benda pasif (isim maf'ül) yang berasal dari kata hakkama-yuhakkimu-tahkiman, yang berarti mengangkat seseorang menjadi hakim dan menyerahkan persoalan hukum kepadanya. Kata muhakkam berarti seseorang yang diangkat sebagai hakim. Lihat Al-Mau'su'at al-Fiqhiyyah al-Kuwaitiyyah, Juz 10 (Cet. II; Kuwait: Dār al-Salāsil), 233. Lihat Pedoman Pegawai Pencatat Nikah dalam Abdurrasyid Ridha, Wali Muhakkam dalam Perkawinan, https://bimasislam.kemenag.go.id/post/opini/ walimuhakkam-dalam-perkawinan-6, diakses pada tanggal 6 Mei 2019. Lihat pula Al-'Alāmah Abū al-Ḥasan al-Māwardiy, al-Hā̄wiy al-Kabīr, Juz 16 (Beirut: Dār al-Fikr, t.th), 649.

${ }^{63}$ Penafsiran gramatikal adalah model penafsiran yang berfungsi menguraikan kataperkata sebuah teks undang-undang menurut arti bahasa umum sehari-hari, dengan kata lain, penafsiran gramatikal adalah penafsiran menurut bahasa setempat atau penafsiran tekstual. Lihat Abdul Manan, Penerapan Hukum Acara Perdata, 279.

${ }^{64}$ Abdul Manan, Penerapan Hukum Acara Perdata, 281. 


\section{Analisis Yuridis terhadap Perkawinan Perempuan Muallaf dengan Wali Nikah Tokoh Agama}

mencukupkan pertimbangan hukumnya hanya pada bunyi teks untuk diterapkan pada kasus nyata, tanpa ada pertimbangan lain. Atau dalam lapangan ilmu hukum konvensional biasa juga disebut dengan metode penafsiran hukum restriktif. ${ }^{65}$ Hal ini mengindikasikan bahwa majelis hakim dalam permohonan iṣbat perkawinan ini, mengikuti mazhab legisme yang dalam istilah usul fikih disebut ijtihad intiqa $\bar{i},{ }^{66}$ di mana hakim berfungsi sebagai penegak undang-undang, tanpa melihat apakah penerapan pasal undang-undang tersebut memenuhi rasa keadilan atau tidak. ${ }^{67}$

Dalam sistem hukum yang disebut kontinental, hukum ditanggapi sebagai terjalin dengan prinsip-prinsip keadilan, hukum adalah undangundang adil. Tentunya pengertian ini serasi dengan ajaran filsafat tradisional, di mana pengertian hukum yang hakiki berkaitan dengan arti hukum sebagai keadilan. Hukum ialah ius atau recht. Bila suatu hukum yang kongkrit, yaitu undang-undang bertentangan dengan prinsip-prinsip keadilan, maka hukum itu tidak bersifat normatif lagi, dan sebenarnya tidak dapat disebut hukum lagi. Undang-undang hanya disebut hukum, bila adil. Dengan kata teknis adil merupakan unsur konstitutif segala pengertian tentang hukum. ${ }^{68}$

Tampaknya kedua majelis hakim dalam mengkualifisir fakta persidangan, menggunakan metode penemuan hukum yang berbeda antara satu dan lainnya, majelis pertama menggunakan teori penafsiran hukum restrikstif yang dalam prakteknya terkesan sangat tekstual dan bergantung pada bunyi teks/pasal secara kaku tanpa menggali latar belakang- dalam

${ }^{65}$ Interpretasi restriktif adalah penafsiran hukum untuk menjelaskan undang-undang dengan cara ruang lingkup ketentuan undang-undang itu dibatasi dengan mempersempit arti suatu peraturan dengan bertitik tolak pada artinya secara bahasa. Abdul Manan, Penerapan Hukum Acara Perdata, 281.

${ }^{66}$ ijtihad intiq $\bar{a}, \bar{i}$ adalah mengambil suatu pendapat ulama terdahulu yang paling kuat untuk berfatwa atau memutus kasus di pengadilan, lawannya adalah ijtihad inshā $\hat{i}$, yang artinya adalah merumuskan hukum baru mengenai masalah tertentu yang sebelumnya tidak ada hukum yang mengatur tentang masalah itu. Lihat Yūsuf al-Qarḍāwìi, al-Ijtihād alMu'așirah bayn al-Indịā̄t wa al-Infirät, (Kairo: Dār al-Tawzì' wa al-Nashr al-Islāmiyah, 1994), 19-32.

${ }^{67}$ Menurut Montesquieu, salah seorang penganut legisme, putusan hakim itu harus dibatasi oleh teks undang-undang, tidak boleh menyimpangi dari undang-undang agar hakim tidak dapat dipengaruhi oleh pendapat pihak luar. Lihat Montesquieu, The Spirit of the Laws, translated by Anne M. Cohler, Basia Carolyn Miller and Harold Samuel Stone (Cambridge: Cambridge University Press, 1992), 158.

${ }^{68}$ T. Huijbers, Filsafat Hukum (Yogyakarta: Kanisius, 2010), 77. 
kasus ini- mengapa sampai kedua mempelai melangsungkan perkawinan dengan menggunakan jasa seorang tokoh agama bukan melalui pejabat yang berwenang yaitu ini Kepala Kantor Urusan Agama Kecamatan. Majelis hakim memposisikan dirinya sebagai corong undang-undang, menyuarakan teks undang-undang tanpa menggali lebih dalam terhadap kearifan lokal (local wisdom) yang melatar belakangi di mana peristiwa nikah itu terjadi.

Sedangkan Majelis Hakim di Pengadilan Singaraja menggunakan pendekatan sebaliknya yaitu metode penafsiran hukum ekstensif yang dalam penerapannya lebih fleksibel dalam menilai fakta-fakta persidangan. Penafsiran model ini tidak lagi terikat pada bunyi teks, tetapi titik tekannya lebih bergantung kepada konteksnya, dalam kasus kedua ini misalnya, terlihat jelas majelis hakim berusaha untuk keluar dari jeratan formalisme Undang-Undang dengan cara menggali latar belakang kasus ini, hal ini secara kasat mata, tampak jelas terlihat ketika dalam pertimbangan hukumnya majelis hakim berusaha untuk mempertimbangkan adat istiadat setempat (local wisdom), untuk dijadikan pijakan awal dalam melakukan contra legem, dengan cara menyimpangi pasal-pasal yang secara tekstual mengatur persyaratan wali nikah. Penulis menilai bahwa majelis hakim dalam kasus ini sudah secara bijak melakukan penemuan hukum (rechtvinding) dengan mempertimbangkan adat istiadat yang berlaku di tempat itu, untuk diterapkan dalam peristiwa aktual.

Tak dapat dihindari berangkat dari dua pendekatan yang berbeda pastilah akan menghasilkan kesimpulan hukum yang tentunya berbeda pula. Meskipun tujuan dari semua putusan/penetapan adalah bermuara kepada memberikan keadilan bagi kedua belah pihak berperkara, tetapi keadilan yang dihasilkan tentu akan berbeda hasilnya menyesuaikan dengan metode penemuan hukum yang dilakukan oleh masing-masing majelis hakim. Dalam simpulan akhirnya Majelis Hakim Pengadilan Agama Sukabumi menggunakan pendekatan restrikstif yang menitikberatkan pada legalitas formal, sebagaimana bunyi teks undang-undang, maka keadilan yang dihasilkan adalah keadilan legal (iustitia legalis), yaitu keadilan berdasarkan undang-undang, ${ }^{69}$ atau disebut dengan keadilan prosedural (procedural justice). Menurut konsep keadilan prosedural, sesuatu dianggap adil apabila pelaksanaan dan putusan hakim selalu mengikuti bunyi pasal-pasal di dalam undang-undang. Jika hakim memutus di luar ketentuan undang-undang bisa dianggap tidak adil karena melanggar kepastian-kepastian yang sudah

${ }^{69}$ T. Huijbers, Filsafat Hukum, 77. 


\section{Analisis Yuridis terhadap Perkawinan Perempuan Muallaf dengan Wali Nikah Tokoh Agama}

ditentukan oleh Undang-Undang. Yang dikatakan adil di dalam keadilan prosedural itu adalah apabila putusan hakim diletakkan pada aturan-aturan resmi yang ada sebelumnya. Ini diperlukan agar ada kepastian bagi orangorang yang akan melakukan sesuatu sehingga bisa memprediksi apa akibat yang akan timbul dari perbuatannya itu. ${ }^{70}$ Putusan dengan model pertimbangan seperti ini, in casu meskipun benar secara legal formal, tetapi memiliki kelemahan dan kekurangan dari sudut pandang social justice. Putusan jenis ini, jika dianalisis dengan mengunakan trisula teori tujuan hukum Gustav Radbruch, ${ }^{71}$ hanya memenuhi unsur kepastian hukum, tetapi mengorbankan kedua unsur yang lain yaitu keadilan dan kemanfaatan hukum, yang semestinya -menurut Rustav- menjadi prioritas ketika terjadi benturan di antara ketiga nilai dasar dari tujuan hukum tersebut. ${ }^{72}$

Sementara untuk kasus yang kedua, karena metode penemuan hukumnya adalah lebih menitik beratkan pada social justice, maka keadilan yang dihasilkan lebih kepada keadilan substansial (substantive justice) yaitu keadilan yang diciptakan oleh hakim dalam putusan-putusannya berdasar hasil galiannya atas rasa keadilan di dalam masyarakat, tanpa dibelenggu bunyi pasal undang-undang yang berlaku. ${ }^{73}$

Dalam kasus di Pengadilan Agama Singaraja, terlihat jelas majelis hakim berusaha untuk keluar dari jeratan formalisme Undang-Undang dengan cara menggali latar belakang kasus ini, hal ini secara kasat mata, tampak jelas terlihat ketika dalam pertimbangan hukumnya majelis hakim berusaha untuk mempertimbangkan adat istiadat setempat (local wisdom), untuk dijadikan pijakan awal dalam melakukan conta legem, dengan cara menyimpangi pasal-pasal yang secara tekstual mengatur persyaratan wali nikah. Sampai di sini, penulis menilai bahwa majelis hakim dalam kasus ini

${ }^{70}$ Moh. Mahmud MD, “Keadilan Substantif” dalam ttps://jurnaltoddoppuli. wordpress.com/2014/09/03/keadilan-substantif/ diakses pada tanggal 20 Mei 2019.

${ }^{71}$ Teori tujuan hukum Gustav Radbruch, pada pokoknya menyatakan bahwa sesuatu yang dibuat pasti memiliki cita atau tujuan, dan hukum dibuat pun ada tujuannya, tujuannya ini merupakan suatu nilai yang ingin diwujudkan manusia, tujuan hukum yang utama ada tiga, yaitu: keadilan untuk keseimbangan; kepastian untuk ketetapan; dan kemanfaatan untuk kebahagiaan.

${ }^{72}$ Bernard L. Tanya, Yoan N. Simanjuntak dan Markus Y. Hage, Teori Hukum: Strategi Tertib Manusia Lintas Ruang dan Generasi (Yogyakarta: Genta Publishing, 2010), 132.

${ }^{73}$ Bernard L. Tanya, Yoan N. Simanjuntak dan Markus Y. Hage, Teori Hukum, 132. 
sudah secara bijak melakukan penemuan hukum (rechtvinding) dengan mempertimbangkan adat istiadat yang berlaku di tempat itu, untuk diterapkan dalam peristiwa aktual. sayangnya majelis hakim dalam perkara ini, dalam pertimbangan hukumnya, tidak menyajikan argumentasi hukum yang jelas terhadap penyimpangan (contra legem) yang dilakukannya. Padahal untuk mengenyampingkan aturan yang sudah diundangkan dalam pasal-pasal suatu perundangan, tidaklah semudah membalikkan telapak tangan, tetapi haruslah betul-betul berdasarkan argumentasi dan rasio hukum (ratio legis) yang jelas, mengapa original content dari suatu pasal itu, disimpangi. Apakah karena kandungan dari pasal-pasal tersebut dipandang tidak relevan lagi jika diterapkan dalam situasi dan kondisi dimana peristiwa hukum itu terjadi, atau karena hal lain yang jika dipaksakan akan menimbulkan ketidakadilan, in casu bagi kedua mempelai?

Sebagai perbandingan, dalam kasus yang sama diputus oleh Pengadilan Agama Waingapu pada tahun 2015, dimana Majelis Hakim sebelum berkesimpulan menetapkan wali nikah tokoh agama sebagai wali muhakkam, mempertimbangkankan terlebih dahulu kondisi sosial masyarakat setempat, yang mana di tempat tersebut di samping pemahaman keagamaan masyarakatnya yang masih rendah, Kantor Urusan Agama sebagai instrumen hukum yang berwenang melakukan pengawasan perkawinan juga tidak berfungsi secara maksimal, sebagai berikut:

Menimbang, bahwa kondisi masyarakat dimana para Pemohon tinggal masih sangat permisif dan tingkat pemahaman-kesadaran norma agama dan hukum yang lemah sehingga banyak ditemukan pasangan yang sudah hidup satu rumah dan memiliki anak tetapi mereka tidak terikat dalam satu perkawinan, sedangkan struktur pemerintah yang membawahi kewenangan melangsungkan dan mencatat perkawinan in casu Kantor Urusan Agama setempat belum secara maksimal dapat difungsikan sehingga kondisi ini darurat dan memaksa tokoh agama setempat untuk berupaya menyelamatkan mereka agar terhindar dari keadaan yang berkelanjutan melanggar norma agama dan hukum maka dilangsungkanlah pernikah Pemohon I dengan Pemohon II dengan wali seorang ustaz/tokoh agama setempat; ${ }^{74}$

Hal inilah yang tidak penulis temukan dalam pertimbangan hukum majelis hakim dalam penetapan a quo, alih-alih untuk memperkuat basis

${ }^{74}$ Lihat Penetapan Nomor 0013/Pdt.P/2015/PA WGP 


\section{Analisis Yuridis terhadap Perkawinan Perempuan Muallaf dengan Wali Nikah Tokoh Agama}

argumentasinya, majelis hakim dalam perkara ini, malah "terjebak" kepada memunculkan (baca: memperluas) norma hukum baru yang belum atau tidak diatur dalam aturan hukum Islam yang berlaku secara positif di Indonesia ${ }^{75}$, yaitu wali muhakkam, yang oleh majelis hakim dalam perkara a quo dipersamakan dengan wali hakim dalam kedudukan dan posisi wali nikah bagi seorang perempuan yang tidak memiliki wali nasab (perempuan muallaf). Sementara dalam literatur fikih klasik, kedudukan wali muhakkam masih menjadi polemik (khiläfiyah) yang berkepanjangan yang tidak menemui titik temunya. Tetapi dari sekian banyak pendapat, tampaknya yang lebih kuat adalah pendapat yang menyatakan bahwa wali muhakkam (tokoh agama misalnya) hanya dapat bertindak menggantikan posisi wali hakim, jika di daerah tersebut tidak atau belum ada wali hakimnya dan si calon pengantin perempuan tersebut memang tidak mempunyai wali nasab, sebagaimana pendapat Imam asy-Syarbaini misalnya, dalam kitabnya Mugni al-Mukhtāj Ilā Ma'rifati Ma'ān̄ Alfāz al-Minhāj. ${ }^{76}$ Hal senada juga diungkapkan oleh Imam al-Qurtū bì dalam kitab tafsirnya al-Jāmi $\bar{\imath}$ ahkāmi al-Qurān Juz III, halaman 76 ketika menafsirkan QS at-Taubah ayat 71. ${ }^{77}$

Realitasnya menunjukkan bahwa hampir seluruh wilayah teritorial Republik Indonesia untuk saat ini, sudah ada Kantor Urusan Agama yang dikepalai oleh seorang penghulu yang berkedudukan sebagai wali hakim bagi perempuan yang tidak memiliki wali, khusunya perempuan muallaf. ${ }^{78}$ Sehingga, pengabulan permohoanan iśbàt nikah dalam kasus yang kedua ini patut dipertanyakan, jika alas hukumnya hanya berdasarkan wali muhakkam yang telah menjadi tradisi di tempat tersebut. Tradisi atau adat-istiadat setempat dapat dipertimbangkan sebagai dasar hukum, sepanjang tidak bertentangan dengan hukum positif yang berlaku. Sebaliknya, jika diterapkan tradisi tersebut justru menggerus eksistensi hukum positif yang telah diundangkan, maka sudah sepatutnya untuk ditinggalkan.

${ }^{75}$ Dalam hukum positif Islam yang berlaku di Indonesia, wali hanya terbagi kepada 2 (dua) jenis, yaitu wali nasab dan wali hakim (Vide Pasal 20 Kompilasi Hukum Islam jo. Pasal 11 ayat (1) Peraturan Menteri Agama RI Nomor 19 Tahun 2018 tentang Pencatatan Perkawinan)

${ }^{76}$ Muhammad al-Khațî̉ as-Syarbainī, Mugnī al-Mukhtāj Ilā Ma'rifati Ma'ān̄̄ Alfăz al-Minhāj, Juz III (Beirut: Dār al-Fikri, t.th.), 147.

${ }^{77}$ Abū 'Abdullāh Muhammad bin Aḥmad bin Abī Bakrin bin Farhin al-Ansāāī alKhajrajn̄i Syamsyuddīn al-Qurțūbī, al-Jāmi’ Li Aḥkāmi al-Qur'ān, Juz III (Riyadh: Dār 'Alim al-Kutūb, 1423 H/2003 M), 76.

${ }^{78}$ Lihat Republik Indonesia, Peraturan Menteri Agama Nomor 19 Tahuhn 2018 tentang Pencatatan Perkawinan, Pasal 12 Ayat (1), (2) dan (3) huruf (e) 


\section{H. Penutup}

Pertimbangan hukum majelis hakim pada Penetapan Nomor 20/Pdt.P/2012/PA.SMI, adalah dengan mempertimbangkan fakta persidangan dimana perkawinan antara Pemohon I dan pemohon II dilangsungkan dengan wali nikah tokoh agama dihubungkan norma hukum yang terkandung dalam pasal pasal 14 dan pasal 20 Kompilasi Hukum Islam, maka majelis hakim berkesimpulan menolak permohonan para Pemohon. Sedangkan pertimbangan hukum majelis hakim pada Penetapan Nomor 6/Pdt.P/2013/Pa. Sgr, adalah dengan mempertimbangkan adat istiadat setempat yang mengakomodir tokoh agama sebagai wali nikah, di samping karena tingkat pemahaman keagamaan masyarakat setempat yang masih relatif kurang, terutama dalam hukum Islam, khususnya bidang perkawinan, maka majelis hakim yang menangani permohonan ini mengabulkan permohonan para Pemohon, meskipun tidak sesuai dengan Pasal 3 Ayat (1), (2) dan (3) Peraturan Menteri Agama Republik Indonesia Nomor 30 Tahun 2005 tentang wali hakim. Dan untuk menguatkan basis argumentasinya majelis hakim melakukan penemuan hukum (rechtsvinding) dengan cara melakukan perluasan makna (penafsiran hukum ekstensif) terhadap terminologi "wali hakim" hingga mencakup pengertian wali muhakkam.

Secara yuridis formil pertimbangan hukum majelis hakim pada Penetapan Nomor 20/Pdt.P/2012/PA.SMI dan Penetapan Nomor 20/Pdt.P/2012/PA.SMI, telah memenuhi syarat-syarat formil. Akan tetapi kedua penetapan tersebut secara karakteristik berbeda. Pada Penetapan Nomor 20/Pdt.P/2012/PA.SMI majelis hakim menggunakan teori penafsiran hukum restrikstif yang dalam prakteknya terkesan sangat tekstual (positivisformalistik) dan bergantung pada bunyi teks/pasal secara kaku tanpa menggali latar belakang di mana peristiwa hukum itu terjadi. Pertimbangan hukum model ini, meurut teori tujuan hukum Gustav Radbruch, hanya memenuhi unsur kepastian hukum, tetapi mengorbankan kedua unsur lain, yang tidak kalah penting dibanding tujuan untuk kepastian hukum, yaitu keadilan dan kemanfaatan hukum, yang semestinya menjadi prioritas ketika terjadi benturan di antara ketiga nilai dasar dari tujuan hukum tersebut. Sedangkan pada Penetapan Nomor 6/Pdt.P/2013/Pa. Sgr, metode yang digunakan oleh majelis hakim, adalah metode penafsiran hukum ekstensif yang dalam penerapannya lebih fleksibel dalam menilai fakta-fakta persidangan. Dalam aplikasinya, penafsiran model ini lebih cenderung 


\section{Analisis Yuridis terhadap Perkawinan Perempuan Muallaf dengan Wali Nikah Tokoh Agama}

melakukan pendekatan yang kontekstual dalam arti tidak hanya melakukan pendekatan secara normatif saja, dengan menerapkan pasal-pasal dalam peraturan perundangan secara legal-formal, tetapi juga mempertimbangkan faktor sosio-kultural masyarakat setempat.

\section{Daftar Pustaka}

Aulawi, Wasit. "Sejarah Perkembangan Hukum Islam," dalam Amrullah Ahmad et.al, Dimensi Hukum Islam dalam Sistem Hukum Nasional. Jakarta: Gema Insani Press, 1996.

AlDāruquthniy, Abū al-Hasan bin 'Umar bin Ahmad bin Mahdi bin Masūd bin Nu'mān bin Dīnār. Sunan Dār al-Quṭni, Juz. III, dalam alMaktabah as-Syāmilah. Cet. I; Beirut, Libanon: Muassasah alRisālah, 2004 M/1424H.

Al-Gazawain̄̄, Muḥammad bin Yazīd Abū 'Abdillāh. Sunan Ibnu Mājah, Bāb Lā Nikāḥa illā biwaliȳ̄, Juz I. Beirut: Dār al-Fikr, t.th.

Huijbers, T. Filsafat Hukum. Yogyakarta: Kanisius, 2010.

Husen, Ibrahim. Fiqh Perbandingan dalam Masalah Nikah Talak dan Rujuk. Jakarta: Yayasan Ihya Ulumuddin, 1971.

Ibn 'Ābidin. Radd al-Mukhtār 'alā Durr al-Mukhtār, Vol. 4. Beirut: Dār alIhyā' al-Turāth al-'Arabī, t.th.

. Hāsyiyah Radd al- Mukhtār 'alā al-Durr al-Mukhtār, Juz IV. Beirut: Dār al-Kutub al-Ilmiyyah, 1994.

Ibn Hanbal, Ahmad. Musnad al-Imām Ahmad bin Hanbal, Juz IV. Kairo: Muassasah Qurtubah, t.th.

Ibn Qudāmah, Al-Mughn̄, Juz VII. Beirut: Dār al-Kutub al- Ilmiyyah, t.th.

Ibnu Qāsim. Fath al-Qan̄b al-Muj̄̄b Fi Syarh Alfādz al-Qan̄o, Juz I. Cet. I; Beirut: Dār Ibn Hazm, 2005 M/1425 H.

Al-Ja'fì, Muhammad bin Ismā'īl Abū 'Abdillāh al-Bukhārī. Al-Jāmi'u asSahīh al-Mukhtaṣar (Sahīh al-Bukhān̄), Bāb as-Syahādah 'alā alAnsāb, Bāb Idzā Aslama as-Ṣābī fa Māta, Juz I. Cet. III; Beirut: Dār Ibn Katsīr, 1987 M/1407 H.

Al-Jazīrī, Abdurraḥmān. Al-Fiqhu 'Alā Mazāhỉb al-Arb'ah, Juz IV. Kairo: al-Maktabah al-Tijāriyah al-Kubra, 1969.

Al-Kasānī, Abī Bakar bin Mas'ūd. Badā'i al-Sanā'i fi Tartīb al-Syara'i, Juz II. Beirut: Dār al-Kutub al-Ilmiyyah, t.th. 
Al-Māwardiy, Al-`Alāmah Abū al-Ḥasan. Al-Ḥāwiy al-Kabīir, Juz 16. Beirut: Dār al-Fikr, t.th.

Mahkamah Agung RI. Himpunan Peraturan Peraturan Perundang-undangan di Lingkungan Peradilan Agama. Jakarta: Direktorat Jenderal Badan Peradilan Agama, 2016.

Manan, Abdul. Aneka Masalah Hukum Perdata Islam di Indonesia. Jakarta: Kencana, 2008.

Montesquieu. The Spirit of the Laws, translated by Anne M. Cohler, Basia Carolyn Miller and Harold Samuel Stone. Cambridge: Cambridge University Press, 1992.

Muhaimin, Abdul Wahab Abd. Reaktualisasi Hukum Islam dalam Konteks Hukum Nasional. Cet. I; Jakarta: Gaung Persada Press, 2017.

Al-Nawāwi, Ab̄̄ Zakariya Muhyddīn bin Syaraf. Al-Majm̄̄' Syarh alMuhazzab, Juz XVI. Beirut: Dār al-Fikr, t.th.

Putusan Nomor 0013/Pdt.P/2015/PA WGP

Putusan Nomor 20/Pdt.P/2013/PA.Smi

Putusan Nomor 6/Pdt.P/2013/Pa. Sgr

Al-Qarḍ̄āìi, Yūsuf. Al-Ijtihād al-Mu'așirah bayn al-Inḍibāt wa al-Infiràt. Kairo: Dār al-Tawzì' wa al-Nashr al-Islāmiyah, 1994.

Al-Qurṭūbī, Abū 'Abdullāh Muḥammad bin Aḥmad bin Ab̄̄ Bakrin bin Farhin al-Ansārī al-Khajrajn̄̄ Syamsyuddīn. Al-Jāmi' Li Ahkāmi alQur'ān, Juz III (Riyadh: Dār 'Alim al-Kutūb, 1423 H/2003 M̀.

Al-Qurtūbī, Abū 'Umar Yūsuf bin 'Abdullāh bin Muhammad. Mawsu'ah Fiqh al-Mālik. Beirut: Dār al-Kutub al-Ilmiyyah, 1992.

Al-Qurthūbī, Abū al-Walīd Muḥammad bin Aḥmad bin Muhammad bin Ahmmad bin Rusyd. Bidāyah al-Mujtahid wa Nihāyah al-Muqtasad, Juz II. Cet. IV; Mesir: Muṣtafā al-Bābī al-Halabī, 1975 M/1395 H.

Ramulyo, Moh. Idris. Hukum Perkawinan Islam: Suatu Analisis dari UU No 1 Tahun 1974 dan KHI. Jakarta: PT Bumi Aksara, 2004.

Republik Indonesia. Peraturan Menteri Agama Nomor 19 Tahun 2018 Tentang Pencatatan Perkawinan.

. Undang-Undang Nomor 3 Tahun 2006 tentang Perubahan UndangUndang Nomor 7 Tahun 1989 tentang Peradilan Agama.

. Undang-Undang Nomor 50 Tahun 2009 tentang Perubahan Kedua Undang-Undang Nomor 7 Tahun 1989 tentang Peradilan Agama. . Undang-Undang Nomor 7 Tahun 1989 tentang Peradilan Agama 


\section{Analisis Yuridis terhadap Perkawinan Perempuan Muallaf dengan Wali Nikah Tokoh Agama}

. Peraturan Menteri Agama RI Nomor 30 Tahun 2005 tentang Wali Hakim

. Peraturan Menteri Agama Nomor 2 Tahun 1987 tentang Wali Hakim

Rofiq, Ahmad. Hukum Islam di Indonesia. Jakarta: PT Raja Grafindo Persada, 1995.

Sābiq, Sayid. Fiqh as-Sunnah Juz II. Cet. III; Beirut: Dār al-Kitāb al-'Arabī, $1977 \mathrm{M} / 1397 \mathrm{H}$.

Al-Syāfi'i, Jalāluddin Muhammad bin Aḥmad bin Muhammad bin Ibrāhīm al-Mahalli. Syarh al-Warqāt fí Usül al-Fiqh, Juz 1. Cet. I; Palestina: Jāmi’ah al-Quds', 1999 M/1420 H.

Al-Syāfi'̀̄. Abu 'Abdillāh Muhammad bin Idrīs. Al-Um, Bāb an-Nikāh bi Walīy, Juz VII. Beirut: Dār al-Ma’rifah, 1393 H.

Al-Syarbainī, Muhammad al-Khațīb. Mugn̄̄ al-Mukhtāj Ilā Ma'rifati Ma'ān̄̄ Alfāz al-Minhāj, Juz III. Beirut: Dār al-Fikri, t.th.

Syarifuddin, Amir. Hukun Perkawinan Islam di Indonesia. Jakarta: Kencana, 2006.

Tanya, Bernard L., Yoan N. Simanjuntak dan Markus Y. Hage, Teori Hukum: Strategi Tertib Manusia Lintas Ruang dan Generasi. Yogyakarta: Genta Publishing, 2010.

Thaib, Hasballah. Hukum Keluarga dalam Syariat Islam. Medan: Universitas Dharmawangsa, 1983.

Timah dan Sohari Sahrani. Fiqih Munakahat Kajian Fiqih Nikah Lengkap. Jakarta: PT Rajawali Press, 2010.

Zahrah, Abū. Ușul al-Fiqh. T.tp.: Dār al-Fikr al-'Arabi, t.th. . Muhādarat fi 'Aqd al-Zīwaj wa Asāruh. Beirut: Dār al-Kutub alIlmiyyah, t.th.

Al-Zuhailī, Wahbah bin Mustafā. Al-Fiqh al-Islāmi wa 'Adillatuh, Juz IX dalam Maktabah Syāmilah. Cet. IV; Damaskus: Dār al-Fikr, t.th.

http://jurnaltoddoppuli. wordpress.com/2014/09/03/keadilan-substantif/

https://bimasislam.kemenag.go.id/post/opini/wali-muhakkam-dalamperkawinan-6 